\title{
Extremely high cytoplasmic diversity in natural and breeding populations of Lolium (Poaceae)
}

\author{
S McGrath ${ }^{1,2}$, TR Hodkinson ${ }^{2}$ and S Barth ${ }^{1}$ \\ ${ }^{1}$ Teagasc Crops Research Centre, Oak Park, Carlow, Ireland and ${ }^{2}$ Department of Botany, School of Natural Sciences, Trinity College \\ Dublin, University of Dublin, Dublin, Ireland
}

\begin{abstract}
Ten chloroplast microsatellite markers were used to characterise chloroplast genetic diversity at allelic and haplotypic level in 104 accessions of Lolium perenne, other Lolium species, Festuca species and $\times$ Festulolium cultivars. Furthermore, genetic relationships between the accessions and biogeographic distribution of haplotypes were investigated using a range of Nei's population genetic diversity measures and analysis of molecular variance (AMOVA). An extremely high number (511) of haplotypes was detected in 1575 individuals. Nei's gene diversity values among L. perenne accessions ranged between 0 and 0.333 . Much
\end{abstract}

of the L. perenne European ecotype diversity (61\%), as calculated using AMOVA, could be attributed to withinpopulation variance and this is likely caused by, and maintained by, high levels of natural and anthropogenic seed dispersal. Plastid gene pools and maternal lineages for $L$. perenne could be clearly identified. Evidence was found, using AMOVA, to show a likely migration route of $L$. perenne from Southern regions of Europe northwards.

Heredity (2007) 99, 531-544; doi:10.1038/sj.hdy.6801030; published online 11 July 2007

Keywords: chloroplast; cytoplasm; Lolium; microsatellites; plastid; Poaceae

\section{Introduction}

Lolium species are highly important forage and turf grasses in Europe and other temperate zones of the world. Perennial ryegrass, Lolium perenne, is the most economically important species within Lolium and is the main constituent of productive pastures (Humphreys et al., 2006). Genetic studies are required for L. perenne to better understand the extent of infraspecific variation, how this diversity is partitioned within and among populations, and to help infer phylogeographic patterns. Chloroplast microsatellite (cpSSR) markers have been previously used successfully to assess variation and chloroplast DNA (cpDNA) diversity in a range of other plant species (Provan et al., 2001; Flannery et al., 2006). cpDNA restriction fragment length polymorphism (RFLP) markers and DNA sequencing have been used to assess the phylogenetic relationships of $L$. perenne to other Lolium and Festuca species (Darbyshire and Warwick, 1992; Charmet et al., 1997; Catalan et al., 1997, 2004; Torrecilla et al., 2004). These studies showed the separation of narrow-leaved fescues (for example, Festuca alpine, Festuca ovina) from the broad-leaved fescues (for example, Festuca arundinacea, Festuca pratensis), with Lolium species grouping either close to the broad-leaved fescue group (Catalan et al., 1997) or within this group (Darbyshire and Warwick, 1992). Within Lolium, self-pollinating species tend to separate phylo-

Correspondence: Dr S Barth, Department of Biotechnology, Teagasc Crops Research Centre, Oak Park, Carlow, Ireland.

E-mail: susanne.barth@teagasc.ie

Received 20 December 2006; revised 18 May 2007; accepted 9 June 2007; published online 11 July 2007 genetically from the open pollinating species. In the study undertaken by Catalan et al. (2004), two autogamous species, Lolium canariense and Lolium rigidum, grouped together while the allogamous species L. perenne grouped with a second allogamous species, Lolium multiflorum.

Genetic characterization of natural and breeding populations of $L$. perenne has so far largely utilized nuclear molecular DNA markers (Cresswell et al., 2001; Bolaric et al., 2005). Few studies have assessed chloroplast or mitochondrial organelle diversity partly because easily applicable organelle markers have until recently not been easily produced (Huang et al., 2002; McGrath et al., 2006). Chloroplast genomes of plants have distinct features. They are generally uniparentally inherited, haploid, non-recombinant and have a conserved gene order (Provan et al., 2001), making cpDNA a useful tool for studying inter-relationships of plants at many taxonomic levels (Catalan et al., 1997; Hodkinson et al., 2002). Although cpDNA generally has lower variability than nuclear DNA (Wolfe et al., 1987), chloroplast simple sequence repeat (cPSSR) loci have been shown to be polymorphic particularly at mononucleotide repeat loci (Powell et al., 1995) and can be used to investigate plant population structure, diversity and differentiation (reviewed by Provan et al., 2001). They can be used to monitor the transmission of chloroplast genomes during hybridization and introgression in wild or breeding populations or to characterize plastid genome type for breeding purposes (Flannery et al., 2006).

cpSSRs can be used in breeding programmes as cultivar identifiers as an addition to nuclear DNA markers (Joshi et al., 1999). Furthermore, detailed 
characterization of plastid type is essential in studies investigating nucleo-cytoplasmic effects (Hallden et al., 1993), since plastid signals controlling nuclear gene expression can have both positive and negative effects on gene expression (Gray, 2005). Several chloroplast genes may have importance for genetic engineering such as those involved in synthesis of fatty acids, amino acids and vitamins (Saski et al., 2005) or for the directed manipulation of plant lines in breeding programmes (Daniell et al., 2005). Worldwide breeding efforts for the improvement of L. perenne and its allies are ongoing and depend upon well-characterized genetic resource collections. Therefore, it is necessary to learn more about the diversity found within it and within closely related species and genera as these form part of the readily accessible gene pool of $L$. perenne for breeding purposes. cpSSR markers have not been used before to study plastid types for plant breeding purposes in Lolium species.

L. perenne is thought to have originated in the Near East, with Europe as a secondary centre of origin (Balfourier et al., 2000). It has subsequently been introduced to almost all of the rest of the temperate world (Charmet et al., 1996). cpDNA RFLP polymorphisms have been used to assess phylogeographic structure in wild-Lolium populations and to infer methods and pathways of geographic migration of Lolium populations (Balfourier et al., 2000). Balfourier et al. (2000) recognized three major clusters of haplotypes in their European sample of Lolium. Their results suggest a single origin for Lolium as well as a geographical structure following an east/west cline, matching known historical processes such as the emergence of agriculture and cereal crops from the Fertile Crescent 10000 years ago and the spread of these crops towards Europe. As yet, cpDNA SSRs have not been used to study plastid diversity in populations of L. perenne or other Lolium species; neither have they been used to study the phylogeography of these species or Festuca species. Given the agronomic importance of $L$. perenne for European agriculture, migration routes from its centres of origin require investigation.

The aims of this study are to (1) describe cpDNA allelic and haplotypic diversity in natural and breeding populations of Lolium including Irish and other European L. perenne ecotypes and bred L. perenne and $\times$ Festulolium cultivars; (2) assess the potential of a set of previously developed cpSSR markers (McGrath et al., 2006) for plastid genome identification and to assess their value for the study of hybridization and introgression and for the definition of cytoplasmic pools in plant breeding; and (3) determine the level of biogeographic population genetic structure in Irish and European L. perenne populations and to gain insights into their phylogeography.

\section{Materials and methods}

In total, 104 grass accessions including $78 \mathrm{~L}$. perenne accessions were studied (Table 1). These 78 accessions consisted of 30 Irish ecotypes, 32 European ecotypes and 16 cultivars. In addition, 11 other Lolium species, 6 Festuca species and $9 \times$ Festulolium cultivars were used. The term ecotype is used broadly in this article to define locally adapted populations. The Irish ecotypes were selected from the Teagasc Oak Park collection holding
419 L. perenne accessions collected from old Irish pasture ecosystems (Connolly, 2000). This collection was made between the years 1980 and 1982 as part of the Lolium Core Collection Project that was coordinated by the European Co-operative Programme for Genetic Resources (ECPGR). The populations originated from collection sites where, according to the farmer, no reseeding had been carried out for 50 years or more. For this study, accessions were selected from the Teagasc Oak Park collection to cover a widespread of diverse geographic regions from the Republic of Ireland. The other European accessions were selected to provide a wide European geographic coverage to allow genetic diversity comparisons to be made with the rest of Europe and to help address possible geographic migration routes of $L$. perenne. The included $\times$ Festulolium cultivars had a defined maternal lineage. The definition of geographic groups was based on the United Nations definition of geographical subregions (United Nations Publication, 1999).

Seeds were germinated on seed testing paper, seedlings transferred to pots and the plants raised in the greenhouse. The ecotype accessions and cultivars were subsequently planted as spaced plants in the field at Oak Park using 50 individual plants per population. Leaf material from generally 16 individuals of each accession was harvested, freeze-dried and ground with a Retsch bead mill. DNA was extracted using a magnetic beadbased method (MagAttract Plant DNA Core kit, Qiagen, Hilden, Germany) as described previously in McGrath et al. (2006). PCR reactions were carried out using the primers developed by, and the thermal cycling parameters used in, McGrath et al. (2006). Ten of the 12 described primers were used: TeaCpSSR1, TeaCpSSR2, TeaCpSSR3, TeaCpSSR4, TeaCpSSR5, TeaCpSSR7, TeaCpSSR8, TeaCpSSR10, TeaCpSSR11 and TeaCpSSR12. PCR products were analysed using an ABI 3100 automated DNA sequencer and alleles were sized using GeneMapper V3.7 software (Applied Biosystems, Warrington, UK).

A genetic distance matrix was calculated based on the Nei's genetic distance measure (Nei, 1972), using allele data (characters) without size information. Distances based on a stepwise mutation model, such as the $\delta \mu^{2}$-distance (Goldstein et al., 1995; Flannery et al., 2006), were not used because the size variation of alleles could be attributed to both SSR length variation and other types of substitutions (non-SSR indels). From this matrix, a dendrogram showing the similarities between populations was constructed using the unweighted pair group method with arithmetic means (UPGMA) method (Sneath and Sokal, 1973) as implemented in POPGENE (Yeh and Boyle, 1997). Bootstrapping analysis was performed on the UPGMA data with 1000 replicates as implemented in NTSYSpc V2.2 software (Rohlf, 2005).

A geographic distance matrix was constructed, using the 56 accessions where an exact geographical origin was known (Table 1). A Mantel test was used to correlate the pairwise comparisons in the geographic distance matrix and the genetic distance matrix using NTSYSpc V2.2 (Rohlf, 2005). A total of 10000 permutations were employed to test for significance.

Since polymorphisms in the chloroplast genome are considered to be linked, each haplotype can be con- 
Table 1 Name, source, original location and genetic diversity information on accessions of Lolium, $\times$ Festulolium and Festuca used in this study

\begin{tabular}{|c|c|c|c|c|c|c|c|c|c|c|c|}
\hline Species & $\begin{array}{l}\text { Accession } \\
\text { number }\end{array}$ & Group $^{\mathrm{a}}$ & $\begin{array}{l}\text { Country } \\
\text { of origin }\end{array}$ & Location & Latitude & Longitude & Seed source & $\mathrm{N}$ & $\mathrm{H}$ & $\begin{array}{c}\mathrm{N} \\
\begin{array}{c}\text { Haplotypes/ } \\
\text { population }\end{array}\end{array}$ & $\begin{array}{l}\mathrm{N} \text { Unique } \\
\text { haplotypes }\end{array}$ \\
\hline L. perenne & IRL-OP-02337 & I 1 & Ireland & Kellistown Farm, Carlow & N 52.47.60 & W 06.49 .73 & Teagasc Oak Park & 15 & 0.180 & 9 & 2 \\
\hline L. perenne & IRL-OP-02059 & I 2 & Ireland & Moyneroe, Scarrif, Clare & N 52.54 .35 & W 08.30 .32 & Teagasc Oak Park & 16 & 0.202 & 12 & 1 \\
\hline L. perenne & IRL-OP-02007 & I 3 & Ireland & Bromcloc, Bantry, Cork & N 51.39 .95 & W 09.31.07 & Teagasc Oak Park & 16 & 0.177 & 11 & 2 \\
\hline L. perenne & IRL-OP-02011 & I 4 & Ireland & $\begin{array}{l}\text { Crowleys Pub, The Square, } \\
\text { Bantry, Cork }\end{array}$ & N 51.42 .15 & W 09.27.67 & Teagasc Oak Park & 14 & 0.207 & 11 & 0 \\
\hline L. perenne & IRL-OP-02015 & I 5 & Ireland & $\begin{array}{l}\text { South Ring, Clonakilty, } \\
\text { Cork }\end{array}$ & N 51.37.10 & W 08.53.71 & Teagasc Oak Park & 16 & 0.268 & 15 & 6 \\
\hline L. perenne & IRL-OP-02048 & I 6 & Ireland & $\begin{array}{l}\text { Carrigeen, Conna, } \\
\text { Old Kents, Fermoy, Cork }\end{array}$ & N 52.05.88 & W 08.03.50 & Teagasc Oak Park & 16 & 0.202 & 10 & 2 \\
\hline L. perenne & IRL-OP-02192 & I 7 & Ireland & $\begin{array}{l}\text { Horse Island, Roaring } \\
\text { Water Bay, West Cork }\end{array}$ & N 51.30.80 & W 09.29.03 & Teagasc Oak Park & 16 & 0.197 & 11 & 1 \\
\hline L. perenne & IRL-OP-02312 & I 8 & Ireland & $\begin{array}{l}\text { Fortlands House, } \\
\text { Charleville, Cork }\end{array}$ & N 52.20.86 & W 08.42.27 & Teagasc Oak Park & 16 & 0.219 & 12 & 3 \\
\hline L. perenne & IRL-OP-02320 & I 9 & Ireland & Clonakilty, Co. Cork & N 51.37.10 & W 08.53.71 & Teagasc Oak Park & 16 & 0.202 & 11 & 3 \\
\hline L. perenne & IRL-OP-02064 & I 10 & Ireland & $\begin{array}{l}\text { Kilreekill, Loughrea, } \\
\text { Galway }\end{array}$ & N 53.13.23 & W 08.28.75 & Teagasc Oak Park & 16 & 0.190 & 10 & 3 \\
\hline L. perenne & IRL-OP-02078 & I 11 & Ireland & $\begin{array}{l}\text { Ballycahalan, Peterswell, } \\
\text { Galway }\end{array}$ & N 53.05.64 & W 08.36 .72 & Teagasc Oak Park & 18 & 0.324 & 15 & 5 \\
\hline L. perenne & IRL-OP-02230 & I 12 & Ireland & $\begin{array}{l}\text { Clough, Cummer, Tuam, } \\
\text { Galway }\end{array}$ & N 53.27.11 & W 08.53.29 & Teagasc Oak Park & 16 & 0.333 & 15 & 8 \\
\hline L. perenne & IRL-OP-02128 & I 13 & Ireland & $\begin{array}{l}\text { Mahera Beg, Commonage } \\
\text { North, Castlegregory, Kerry }\end{array}$ & N 52.17.79 & W 10.01.38 & Teagasc Oak Park & 16 & 0.122 & 5 & 3 \\
\hline L. perenne & IRL-OP-02538 & I 14 & Ireland & Colt, Ballyroan, Laois & N 52.58.08 & W 07.20.70 & Teagasc Oak Park & 16 & 0.198 & 8 & 2 \\
\hline L. perenne & IRL-OP-02274 & I 15 & Ireland & $\begin{array}{l}\text { Buffanoka, Cappamore, } \\
\text { Limerick }\end{array}$ & N 52.39.29 & W 08.18 .62 & Teagasc Oak Park & 16 & 0.174 & 9 & 1 \\
\hline L. perenne & IRL-OP-02480 & I 16 & Ireland & $\begin{array}{l}\text { Inch St, Lawrence, } \\
\text { Caherconlish, Limerick }\end{array}$ & N 52.35.47 & W 08.30.99 & Teagasc Oak Park & 16 & 0.276 & 16 & 5 \\
\hline L. perenne & IRL-OP-02442 & I 17 & Ireland & $\begin{array}{l}\text { Doughmakean, Roonagh, } \\
\text { Westport, Mayo }\end{array}$ & N 53.44 .74 & W 09.53.69 & Teagasc Oak Park & 16 & 0.270 & 15 & 3 \\
\hline L. perenne & IRL-OP-02444 & I 18 & Ireland & $\begin{array}{l}\text { Barnabawn, Killadoon, } \\
\text { Westport, Mayo }\end{array}$ & N 53.41.48 & W 09.54.91 & Teagasc Oak Park & 16 & 0.191 & 10 & 1 \\
\hline L. perenne & IRL-OP-02068 & I 19 & Ireland & $\begin{array}{l}\text { Ballycommon, Tullamore, } \\
\text { Offaly }\end{array}$ & N 53.17.50 & W 07.23.11 & Teagasc Oak Park & 15 & 0.287 & 14 & 7 \\
\hline L. perenne & IRL-OP-02241 & I 20 & Ireland & Clonohill, Birr, Offaly & N 53.05.20 & W 07.53 .73 & Teagasc Oak Park & 16 & 0.253 & 13 & 6 \\
\hline L. perenne & IRL-OP-02419 & I 21 & Ireland & $\begin{array}{l}\text { Johnstown,Cornafulla, } \\
\text { Athlone, Roscommon }\end{array}$ & N 53.38.05 & W 09.30.71 & Teagasc Oak Park & 16 & 0.253 & 14 & 4 \\
\hline L. perenne & IRL-OP-02258 & I 22 & Ireland & The Lawn, Drum, Tipperary & N 52.46.32 & W 07.52.89 & Teagasc Oak Park & 16 & 0.191 & 11 & 3 \\
\hline L. perenne & IRL-OP-02272 & I 23 & Ireland & $\begin{array}{l}\text { Ballycrana, Kilross, } \\
\text { Tipperary }\end{array}$ & N 52.25.28 & W 08.15.88 & Teagasc Oak Park & 16 & 0.301 & 16 & 6 \\
\hline L. perenne & IRL-OP-02250 & I 24 & Ireland & $\begin{array}{l}\text { Glown, Upperchurch, } \\
\text { Tipperary }\end{array}$ & N 52.42 .55 & W 08.07.99 & Teagasc Oak Park & 17 & 0.260 & 13 & 3 \\
\hline L. perenne & IRL-OP-02267 & I 25 & Ireland & $\begin{array}{l}\text { Ballyhoulihan, Emly, } \\
\text { Tipperary }\end{array}$ & N 52.26.88 & W 08.22.06 & Teagasc Oak Park & 16 & 0.292 & 15 & 4 \\
\hline L. perenne & IRL-OP-02269 & I 26 & Ireland & $\begin{array}{l}\text { Ballycurrane, Emly, } \\
\text { Tipperary }\end{array}$ & N 52.27.42 & W 08.22.95 & Teagasc Oak Park & 17 & 0.248 & 15 & 2 \\
\hline L. perenne & IRL-OP-02173 & I 27 & Ireland & $\begin{array}{l}\text { Deerpark, Lismore, } \\
\text { Waterford }\end{array}$ & N 52.08.04 & W 07.55.62 & Teagasc Oak Park & 16 & 0.273 & 12 & 3 \\
\hline L. perenne & IRL-OP-02483 & I 28 & Ireland & $\begin{array}{l}\text { Edwardstown, Cleriestown, } \\
\text { Wexford }\end{array}$ & N 52.16.20 & W 06.38.25 & Teagasc Oak Park & 16 & 0.262 & 16 & 1 \\
\hline
\end{tabular}


Table 1 Continued

\begin{tabular}{|c|c|c|c|c|c|c|c|c|c|c|c|}
\hline Species & $\begin{array}{l}\text { Accession } \\
\text { number }\end{array}$ & Group $^{\mathrm{a}}$ & $\begin{array}{l}\text { Country } \\
\text { of origin }\end{array}$ & Location & Latitude & Longitude & Seed source & $\mathrm{N}$ & $\mathrm{H}$ & $\begin{array}{c}\mathrm{N} \\
\text { Haplotypes/ } \\
\text { population }\end{array}$ & $\begin{array}{l}\mathrm{N} \text { Unique } \\
\text { haplotypes }\end{array}$ \\
\hline L. perenne & IRL-OP-02491 & I 29 & Ireland & $\begin{array}{l}\text { Heath Park, Newbawn, } \\
\text { Wexford }\end{array}$ & N 52.23.32 & W 06.48.61 & Teagasc Oak Park & 16 & 0.248 & 14 & 2 \\
\hline L. perenne & IRL-OP-02018 & I 30 & Ireland & $\begin{array}{l}\text { Ballynure Demesne, } \\
\text { Grangecon, Wicklow }\end{array}$ & N 52.59 .95 & W 06.44 .92 & Teagasc Oak Park & 16 & 0.286 & 14 & 6 \\
\hline L. perenne & GR 5092 & $\Delta 1$ & Germany & Malchow/Poel & N 54.00.00 & E 11.28 .00 & IPK Gatersleben & 16 & 0.199 & 12 & 2 \\
\hline L. perenne & PI 598445 & $\Delta 2$ & Netherlands & s Unknown & N 53.07 .00 & E 07.02.00 & GRIN & 12 & 0.146 & 8 & 0 \\
\hline L. perenne & ABY-Ba 12896 & $\Delta 3$ & Denmark & Unknown & N 55.00.00 & Е 09.46.59 & IGER & 16 & 0.128 & 8 & 5 \\
\hline L. perenne & NGB14250 & $\Delta 4$ & Sweden & Unknown & N 57.45.50 & E 14.51.25 & Nordic Gene Bank & 12 & 0.285 & 11 & 3 \\
\hline L. perenne & 16-7-62-2 Nordic & $\Delta 5$ & Norway & Sola & N 58.54.00 & W 05.34 .99 & Teagasc Oak Park & 16 & 0.268 & 13 & 6 \\
\hline L. perenne & PI 619024 & $\Delta 6$ & England & Unknown & N 53.17.00 & W 01.46 .00 & GRIN & 12 & 0.106 & 6 & 2 \\
\hline L. perenne & W6 9339 & $\Delta 7$ & Wales & Unknown & N 51.57.00 & W 03.03.00 & GRIN & 16 & 0.247 & 14 & 2 \\
\hline L. perenne & PI 610958 & $\square 8$ & Tunisia & Unknown & N 36.53.42 & Е 09.11.13 & GRIN & 16 & 0.260 & 14 & 7 \\
\hline L. perenne & ABY-Ba 11315 & $\square 9$ & Morocco & Unknown & N 31.30 .00 & W 09.48 .00 & IGER & 16 & 0.206 & 12 & 5 \\
\hline L. perenne & E1 & $\square 10$ & Egypt & Unknown & Unknown & Unknown & PGG-Wrightson & 16 & 0.066 & 4 & 3 \\
\hline L. perenne & W6 11325 & $\Delta 11$ & Turkey & Karabuk, Ankara & N 41.07.12 & E 32.22 .12 & GRIN & 16 & 0.114 & 6 & 1 \\
\hline L. perenne & PI 598512 & $\mathbf{\Delta} 12$ & Turkey & Antalya & N 36.54.45 & E 30.41 .23 & GRIN & 16 & 0.188 & 9 & 2 \\
\hline L. perenne & PI 547390 & $\mathbf{\Delta} 13$ & Iran & Karaj & N 35.28.48 & E 51.00 .00 & GRIN & 12 & 0.118 & 5 & 1 \\
\hline L. perenne & PI 317452 & $\Delta 14$ & Afghanistan & $\begin{array}{l}\text { North of Hari Rud River, } \\
4 \text { miles West of Besha }\end{array}$ & N 34.46 .00 & Е 63.46 .00 & GRIN & 16 & 0.165 & 9 & 1 \\
\hline L. perenne & No 10 Spain & $\mathbf{\square} 15$ & Spain & Unknown & Unknown & Unknown & Teagasc Oak Park & 16 & 0.250 & 13 & 6 \\
\hline L. perenne & 3408 Italy & $\mathbf{\square} 16$ & Italy & Unknown & Unknown & Unknown & Teagasc Oak Park & 16 & 0.264 & 15 & 4 \\
\hline L. perenne & W6 16127 & $\mathbf{\square} 17$ & Italy & Sardinia & $\mathrm{N} 40.34 .37$ & Е 09.12.18 & GRIN & 15 & 0.191 & 9 & 8 \\
\hline L. perenne & 3013 Romania & $\mathbf{\square} 18$ & Romania & Unknown & Unknown & Unknown & Teagasc Oak Park & 17 & 0.235 & 15 & 3 \\
\hline L. perenne & $\begin{array}{l}3199 \text { Romania } \\
\text { Podoloni }\end{array}$ & $\mathbf{\square} 19$ & Romania & Unknown & Unknown & Unknown & Teagasc Oak Park & 16 & 0.235 & 14 & 0 \\
\hline L. perenne & 920 Bulgaria & $\boldsymbol{\square} 20$ & Bulgaria & Unknown & Unknown & Unknown & Teagasc Oak Park & 16 & 0.206 & 11 & 0 \\
\hline L. perenne & PI 418701 & [ 21 & Yugoslavia & Prizren & N 42.13.00 & E 22.44.00 & GRIN & 16 & 0.120 & 6 & 1 \\
\hline L. perenne & ABY-Ba 11478 & $\mathbf{\square} 22$ & Greece & Unknown & N 38.00 .00 & E 22.10.00 & IGER & 16 & 0.132 & 14 & 3 \\
\hline L. perenne & W6 9286 & $\bigcirc 23$ & France & Unknown & N 47.33.00 & E 04.28 .00 & GRIN & 16 & 0.155 & 9 & 3 \\
\hline L. perenne & ABY-Ba 11514 & $\bigcirc 24$ & France & Unknown & N 49.57.00 & E 02.46 .00 & IGER & 16 & 0.182 & 10 & 3 \\
\hline L. perenne & CPI 44924 & $\bigcirc 25$ & France & Arles & N 43.40.01 & E 04.37.58 & PGG-Wrightson & 16 & 0.205 & 11 & 7 \\
\hline L. perenne & GR 5095 & $\bigcirc 26$ & Germany & Kempten & N 47.49 .00 & Е 10.19 .59 & IPK Gatersleben & 16 & 0.205 & 12 & 3 \\
\hline L. perenne & GR 5105 & $\bigcirc 27$ & Germany & Kempten & N 47.49 .59 & E 10.15.00 & IPK Gatersleben & 16 & 0.238 & 12 & 5 \\
\hline L. perenne & PI 274637 & $\bullet 28$ & Poland & Lublin & N 51.13.48 & Е 22.33.00 & GRIN & 16 & 0.158 & 10 & 1 \\
\hline L. perenne & PI 267058 & $\cdot 29$ & Poland & Warszawa & N 52.35 .00 & E 21.05.00 & GRIN & 16 & 0.099 & 5 & 1 \\
\hline L. perenne & PI 182857 & $\bullet 30$ & $\begin{array}{l}\text { Czech } \\
\text { Republic }\end{array}$ & Central Bohemia & Unknown & Unknown & GRIN & 16 & 0.232 & 6 & 6 \\
\hline L. perenne & PI 321397 & $\bullet 31$ & $\begin{array}{l}\text { Czech } \\
\text { Republic }\end{array}$ & Central Bohemia & Unknown & Unknown & GRIN & 16 & 0.232 & 12 & 5 \\
\hline L. perenne & $\begin{array}{l}\text { IV-51-161 } \\
\text { Hungary }\end{array}$ & $\bullet 32$ & Hungary & Unknown & Unknown & Unknown & Teagasc Oak Park & 16 & 0.245 & 14 & 6 \\
\hline L. perenne & cv. Aurora & V 1 & NA & NA & NA & NA & IGER & 17 & 0.249 & 12 & 1 \\
\hline L. perenne & cv. Barlenna & V 2 & NA & NA & NA & NA & Barenbrug Holland BV & 16 & 0.229 & 10 & 5 \\
\hline L. perenne & cv. Cancan & V 3 & NA & NA & NA & NA & DLF-Trifolium & 16 & 0.302 & 15 & 6 \\
\hline L. perenne & cv. Cashel & V 4 & NA & NA & NA & NA & Teagasc & 16 & 0.172 & 5 & 1 \\
\hline L. perenne & cv. Fennema & V 5 & NA & NA & NA & NA & $\begin{array}{l}\text { Norddeutsche } \\
\text { Pflanzenzucht }\end{array}$ & 16 & 0.207 & 11 & 3 \\
\hline L. perenne & cv. Greengold & V 6 & NA & NA & NA & NA & Teagasc & 17 & 0.161 & 9 & 0 \\
\hline L. perenne & cv. Magician & V 7 & NA & NA & NA & NA & Teagasc & 16 & 0.254 & 14 & 3 \\
\hline
\end{tabular}


Table 1 Continued

\begin{tabular}{|c|c|c|c|c|c|c|c|c|c|c|c|}
\hline Species & $\begin{array}{l}\text { Accession } \\
\text { number }\end{array}$ & Group $^{\mathrm{a}}$ & $\begin{array}{l}\text { Country } \\
\text { of origin }\end{array}$ & Location & Latitude & Longitude & Seed source & $\mathrm{N}$ & $\mathrm{H}$ & $\begin{array}{c}\mathrm{N} \\
\text { Haplotypes/ } \\
\text { population }\end{array}$ & $\begin{array}{l}\mathrm{N} \text { Unique } \\
\text { haplotypes }\end{array}$ \\
\hline L. perenne & cv. Millenium & V 8 & NA & NA & NA & NA & Teagasc & 16 & 0.157 & 9 & 0 \\
\hline L. perenne & cv. Navan & V 9 & NA & NA & NA & NA & DARDNI & 16 & 0.272 & 11 & 4 \\
\hline L. perenne & cv. Odenwaelder & V 10 & NA & NA & NA & NA & IPK Gatersleben & 16 & 0.259 & 14 & 4 \\
\hline L. perenne & cv. Portstewart & V 11 & NA & NA & NA & NA & DARDNI & 16 & 0.193 & 9 & 3 \\
\hline L. perenne & cv. Premo & V 12 & NA & NA & NA & NA & $\begin{array}{l}\text { Mommersteeg } \\
\text { International BV }\end{array}$ & 16 & 0.167 & 9 & 0 \\
\hline L. perenne & cv. S24 & V 13 & NA & NA & NA & NA & IGER & 17 & 0.199 & 12 & 5 \\
\hline L. perenne & cv. Sarsfield & V 14 & NA & NA & NA & NA & Teagasc & 16 & 0.238 & 12 & 2 \\
\hline L. perenne & cv. Shandon & V 15 & NA & NA & NA & NA & Teagasc & 16 & 0.213 & 11 & 2 \\
\hline L. perenne & cv. Talbot & V 16 & NA & NA & NA & NA & $\begin{array}{l}\text { Van der Have } \\
\text { Grasses BV }\end{array}$ & 16 & 0.235 & 13 & 3 \\
\hline L. canariense & PI 320544 & L 1 & $\begin{array}{l}\text { Canary } \\
\text { Islands }\end{array}$ & $\begin{array}{l}\text { Iqueste de San Andres, } \\
\text { Tenerife }\end{array}$ & N 110.36 .00 & E 12.00 .29 & GRIN & 16 & 0.239 & 7 & 7 \\
\hline L. hybridum & ABY-Ba 13122 & L 2 & Portugal & Unknown & N 40.56.00 & W. 07.33.00 & IGER & 16 & 0.157 & 9 & 9 \\
\hline L. hybridum & GR11849/94 & L 3 & NA & Unknown & Unknown & Unknown & IPK Gatersleben & 8 & 0.109 & 5 & 3 \\
\hline L. multiflorum & GR11855/98 & $\mathrm{L} 4$ & NA & Unknown & Unknown & Unknown & IPK Gatersleben & 8 & 0.231 & 6 & 6 \\
\hline L. persicum & PI 229764 & L 5 & Iran & Unknown & Unknown & Unknown & GRIN & 16 & 0.065 & 3 & 4 \\
\hline L. remotum & GR11839/99a & L 6 & Germany & Unknown & Unknown & Unknown & IPK Gatersleben & 8 & 0.052 & 3 & 3 \\
\hline L. rigidum & GR11848/91 & L 7 & Iran & $\begin{array}{l}\text { Between Kalafabad and } \\
\text { Ramhormos }\end{array}$ & Unknown & Unknown & IPK Gatersleben & 8 & 0.066 & 4 & 4 \\
\hline L. subulatum & PI 197310 & L 8 & Argentina & Unknown & Unknown & Unknown & GRIN & 16 & 0.156 & 6 & 7 \\
\hline L. temulentum & ABY-Ba 13643 & L 9 & Morocco & Unknown & N 35..34.00 & W 05.22.00 & IGER & 16 & 0.227 & 13 & 11 \\
\hline L. temulentum & ABY-Ba 8917 & L 10 & Iran & Unknown & N 52.19.00 & Е 36.25 .59 & IGER & 16 & 0.174 & 9 & 9 \\
\hline L. temulentum & GR11880/82 & L 11 & Italy & $\begin{array}{l}\text { South of Monte Mutry, } \\
1 \mathrm{~km} \text { east of } \\
\text { Santa Crocella }\end{array}$ & Unknown & Unknown & IPK Gatersleben & 8 & 0.147 & 5 & 6 \\
\hline$\times$ Festulolium braunii & cv. Perun & F 1 & NA & NA & NA & NA & $\begin{array}{l}\text { Plant Breeding Station } \\
\text { Hladke Zivotice }\end{array}$ & 16 & 0.240 & 13 & 9 \\
\hline$\times$ Festulolium braunii & cv. HD 14 DK & F 2 & NA & NA & NA & NA & $\begin{array}{l}\text { Plant Breeding Station } \\
\text { Hladke Zivotice }\end{array}$ & 16 & 0.247 & 13 & 6 \\
\hline$\times$ Festulolium braunii & cv. Paulita & F 3 & NA & NA & NA & NA & $\begin{array}{l}\text { Plant Breeding Station } \\
\text { Hladke Zivotice }\end{array}$ & 16 & 0.207 & 11 & 4 \\
\hline$\times$ Festulolium braunii & cv. Achilles & F 4 & NA & NA & NA & NA & $\begin{array}{l}\text { Plant Breeding Station } \\
\text { Hladke Zivotice }\end{array}$ & 16 & 0.187 & 10 & 1 \\
\hline $\begin{array}{l}\times \text { Festulolium Lolium } \\
\text { multiflorum } \times \text { Festuca } \\
\text { arundinacea } B C \text { to } \\
\text { F. arundinacea }\end{array}$ & cv. Lesana & F 5 & NA & NA & NA & NA & $\begin{array}{l}\text { Plant Breeding Station } \\
\text { Hladke Zivotice }\end{array}$ & 16 & 0.213 & 13 & 0 \\
\hline $\begin{array}{l}\times \text { Festulolium Lolium } \\
\text { multiflorum } \times \text { Festuca } \\
\text { arundinacea } B C \text { to } \\
\text { F. arundinacea }\end{array}$ & cv. Korina & F 8 & NA & NA & NA & NA & $\begin{array}{l}\text { Plant Breeding Station } \\
\text { Hladke Zivotice }\end{array}$ & 16 & 0.215 & 11 & 0 \\
\hline $\begin{array}{l}\times \text { Festulolium Lolium } \\
\text { multiflorum } \times \text { Festuca } \\
\text { arundinacea } B C \text { to } \\
\text { F. arundinacea }\end{array}$ & cv. Felina & F 9 & NA & NA & NA & NA & $\begin{array}{l}\text { Plant Breeding Station } \\
\text { Hladke Zivotice }\end{array}$ & 12 & 0.214 & 8 & 1 \\
\hline $\begin{array}{l}\times \text { Festulolium Lolium } \\
\text { multiflorum } \times \text { Festuca } \\
\text { arundinacea } B C \text { to } \\
\text { L. multiflorum }\end{array}$ & cv. Becva & F 6 & NA & NA & NA & NA & $\begin{array}{l}\text { Plant Breeding Station } \\
\text { Hladke Zivotice }\end{array}$ & 16 & 0.251 & 13 & 1 \\
\hline
\end{tabular}


sidered as one allele at a single haploid locus. Allele size information was used to construct haplotypes. Haplotype frequencies were used to calculate Nei's (1973) gene diversity $(H)$ and the total diversity $\left(H_{\mathrm{t}}\right)$, the mean within-population diversity $\left(H_{\mathrm{s}}\right)$ and the coefficient of variation $\left(G_{\mathrm{st}}\right)$ following the procedures of Nei (1987) using the program POPGENE (Yeh and Boyle, 1997).

An analysis of molecular variance (AMOVA; Excoffier et al., 1992) was carried out with ARLEQUIN 2.0 software (Schneider et al., 2000) based on the number of different haplotypes, which is the equivalent of a weighted $F_{\text {st }}$ over all loci when estimating genetic structure (Weir and Cockerham, 1984; Michalakis and Excoffier, 1996). The level of significance for variance component estimates was calculated by non-parametric permutation procedures using 1000 permutations. The data were partitioned in several combinations to display among- and within-population variation of Irish and European L. perenne accessions, to assess biogeographic differentiation and to address possible migration routes of L. perenne.

AMOVAs were calculated to test for evidence of geographic patterns of genetic structuring. In addition, we used AMOVAs to test if there was evidence of migration of Lolium (a) following a Mediterranean route, this involved comparisons of Near Eastern vs Southern European and Southern European vs Western European L. perenne accession groups; (b) following a Danubian migration route, this involved comparisons of Near Eastern vs Southern European, Southern European vs Eastern European and Eastern European vs Northern European L. perenne accession groups; (c) following a Northern African route, this involved comparisons of Near Eastern vs Northern African and Northern Africa vs Southern European L. perenne accession groups; (d) following a northerly retreat route of the glaciers after the last ice age, this involved comparison of all L. perenne ecotype groups south of the Alps (Near East, North Africa and Southern Europe) against all L. perenne ecotype groups North of the Alps (Northern Europe, Eastern Europe, Western Europe, Ireland); and (e) following routes into Ireland consistent with migration from neighbouring geographical regions, this involved comparisons of Irish L. perenne ecotypes with three European accession groups (Southern Europe, Western Europe and Northern Europe).

An Edward's Venn diagram was constructed to display shared haplotypes between six accession groups: Irish L. perenne ecotypes, European/Near Eastern L. perenne ecotypes, L. perenne cultivars, other Lolium species, $\times$ Festulolium cultivars and Festuca species. A second Edward's Venn diagram was constructed to display shared haplotypes between seven $L$. perenne accession groups: Irish ecotypes, Northern European ecotypes, Western European ecotypes, Southern European ecotypes, Eastern European ecotypes, North African ecotypes and Near Eastern ecotypes.

From the genetic distance matrix, a dendrogram showing the similarities between six major groups of accessions was constructed using UPGMA (Sneath and Sokal, 1973) as implemented in POPGENE (Yeh and Boyle, 1997). Bootstrapping analysis was performed on the UPGMA data with 1000 replicates as implemented in NTSYSpc V2.2 software (Rohlf, 2005). 


\section{Results}

\section{Allelic variation}

All ten cpSSR marker loci used in this analysis of 1575 individuals were found to be polymorphic, ranging from marker TeaCpSSR7 with 4 alleles to marker TeaCpSSR3 with 22 alleles (Table 2). The distribution of alleles in the populations varied between $L$. perenne ecotypes, L. perenne cultivars and the groups of other species. At locus TeaCpSSR8, there was only one allele present in the $\times$ Festulolium cultivars, but ten alleles present in Irish L. perenne ecotypes. Loci TeaCpSSR3 and TeaCpSSR8 had the largest number of alleles for L. perenne ecotypes. Loci TeaCpSSR2, TeaCpSSR3 and TeaCpSSR5 had the largest number of alleles for $L$. perenne cultivars. Locus TeaCpSSR3 was extremely rich in alleles, including 11 alleles for the other tested Lolium species.

Generally, there were more alleles unique to $L$. perenne ecotypes than in all the other species groups. Marker locus TeaCpSSR8 was the richest locus for unique alleles in $L$. perenne in general. There were five alleles unique to the Irish L. perenne ecotypes, five alleles unique to the European/Near Eastern ecotypes and one allele unique to the other Lolium species. None of the alleles at this locus was unique to the $\times$ Festulolium cultivars or to Festuca species. Locus TeaCpSSR7 was an exception with no allele being unique to $L$. perenne accessions. None of the alleles, across all loci, was diagnostic by itself for a single population, but some were for a defined group of populations. However, unique alleles were present only in groups containing more than one allele. Three alleles were unique for non-L. perenne Lolium species (at loci TeaCpSSR3 and TeaCpSSR8). Generally across all ten marker loci, no unique alleles for Festuca and $\times$ Festulolium accessions were found (Table 2).

An UPGMA dendrogram showing the similarities between all 104 populations was constructed and it produced groupings that were similar to the UPGMA analysis of 11 defined groups of accessions (Figure 1). For this reason only the latter dendrogram is shown. The dendrogram of all 104 accessions is provided as Supplementary Information (Supplementary Material A).

The UPGMA dendrogram showing the similarities between the 11 groups of accessions was constructed to support the AMOVA analysis (below) and to investigate the broad-scale geographical structuring (Figure 1). The group of Festuca species were outlying all other groups (Figure 1, group I). The rest of the dendrogram was split into two major groups (Figure 1, groups II and III). The first group (II) contained the Irish L. perenne ecotypes, the L. perenne cultivars, the Lolium species and the $\times$ Festulolium cultivars. The second group (III) contained all European/Near Eastern L. perenne ecotypes and could be split into two subgroups (IIIa and IIIb). Subgroup IIIa consisted of the Southern European, Western European and Northern European ecotypes, while subgroup IIIb consisted of the North African, Near Eastern and Eastern European ecotypes. There was moderate-to-good bootstrap support for many branches of the tree.

A Mantel test to check for a correlation between genetic distances and geographic distances among 56 accessions out of 62 ecotypes resulted only in a weak and nonsignificant correlation $(r=0.338)$

\section{Haplotypic variation}

The 104 tested populations had a large amount of haplotypic variation (Table 1 and Figure 2). Of the 511 haplotypes present, 366 of these were unique to individual populations. Generally with a few exceptions, each of the 104 populations had a range of unique haplotypes (Table 1). Nine populations had no unique haplotypes, while four populations (L. temulentum L10, F. arundinacea, F. gigantea and F. pratensis) were composed of completely unique haplotypes (Table 1). No single haplotype was present in all groups of populations. One hundred and twelve of the haplotypes were only present in Irish L. perenne ecotypes (Figure 2) of which 98 were unique to single populations. Thus 15 haplotypes were shared only among Irish L. perenne ecotypes and were diagnostic for these accessions (Supplementary Material B). One hundred and twenty-four haplotypes were unique to European L. perenne ecotypes of which 105 were unique to single populations. Twenty haplotypes could be considered as diagnostic for European $L$. perenne ecotype accessions (Supplementary Material B), especially for ecotypes of the Northern European and Western European geographical regions. Forty-five haplotypes were found only in L. perenne cultivars of which 42 haplotypes were unique to single populations. Three haplotypes were shared among L. perenne cultivars (Supplementary material B), and were found in cultivars 'Aurora', 'Cancan', 'Magician' and 'Shandon'. Fifty-two unique haplotypes were detected in $\times$ Festulolium cultivars of which 32 were unique to single populations. Seventy-four haplotypes were specific to other Lolium species of which 69 were unique to single populations. Twenty-one haplotypes were found to be specific for Festuca species of which 20 were unique to single populations. In total, 29 haplotypes were shared between $\times$ Festulolium accessions and Lolium accessions, of which 26 haplotypes were shared with $L$. perenne ecotypes (Figure 2).

Nei's gene diversity values ( $H$; Nei, 1972) among L. perenne accessions ranged between 0 (NL1 and NL4) and 0.333 with the Irish ecotype I 12 (Table 1). Only one haplotype was present in the F. arundinacea and F. ovina populations, thus their $H$ values were 0 . The lowest $H$ value of 0.052 was found in a $L$. remotum population (L6, Table 1). $H$ values were higher in the Irish and European/Near Eastern L. perenne ecotypes ranging between 0.211 and 0.219 . In the other groups of accessions, values for cultivars were $H=0.145$, other Lolium species $H=0.187, \times$ Festulolium cultivars $H=0.086$ and Festuca species $H=0.148$. The total gene diversity $\left(H_{\mathrm{t}}\right.$; Table 3$)$ ranged from Near Eastern L. perenne accessions $\left(H_{\mathrm{t}}=0.233\right)$ to Southern European L. perenne accessions $\left(H_{\mathrm{t}}=0.359\right)$. $H_{\mathrm{t}}$ values for other accession groups were within this range. The gene diversity within subdivided populations $\left(H_{\mathrm{s}}\right)$ ranged between 0.077 for Festuca species and 0.238 for Irish L. perenne ecotypes. The highest $H_{\mathrm{s}}$ value in the Irish L. perenne ecotypes was closely followed by the value for $\times$ Festulolium accessions $\left(H_{\mathrm{s}}=0.227\right)$. The $H_{\mathrm{s}}$ value for Near Eastern L. perenne ecotypes was the lowest $\left(H_{\mathrm{s}}=0.146\right)$ among L. perenne accessions. As $G_{\mathrm{st}}$ becomes closer to one, the populations within the groups are more markedly different from each other. $G_{\text {st }}$ values ranged from 0.238 in the Irish L. perenne ecotypes to 0.716 in the Festuca species. 
538

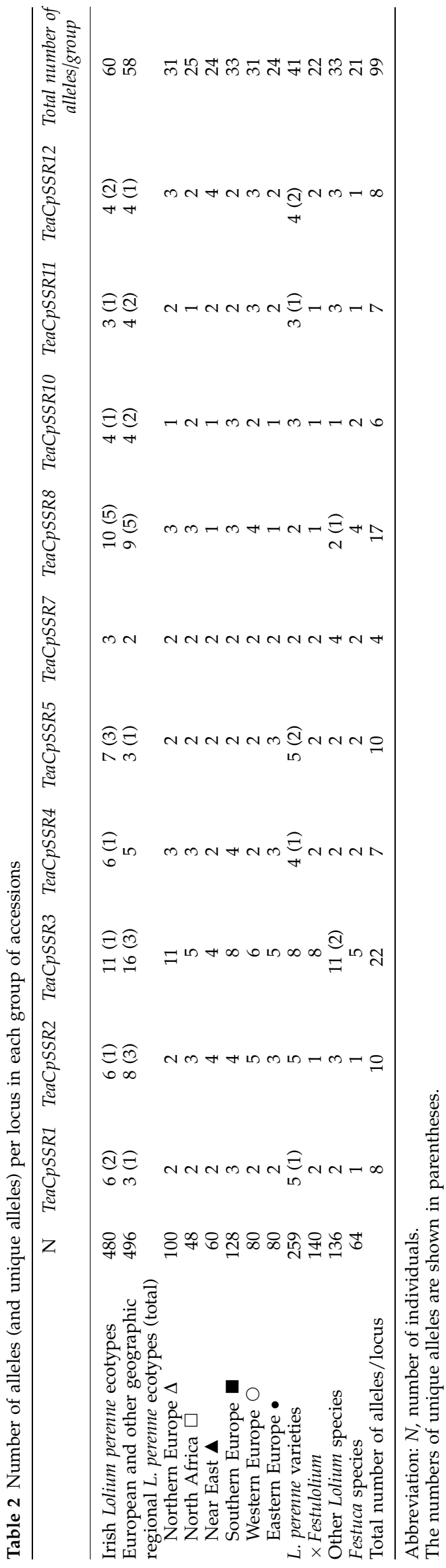

AMOVA analysis

AMOVA analysis was carried out on 15 different subgroups of accessions, to test for differences in genetic structure within and between Irish and European ecotypes, to test possible geographic migration routes and to test for differences between and within $L$. perenne accessions and $\times$ Festulolium cultivars (Table 4). In general, the variation among populations accounted for less of the total variation than that found within populations, for example, for the Irish and European L. perenne ecotype comparison, the within-population variation accounted for $63 \%$ of total variation. Amongpopulation variation accounted for $26 \%$ of total variation and among-group variation accounted for $11 \%$ of total variation. These results were comparable to the variation found within and among partitions in the L. perenne and $\times$ Festulolium comparison (64\% within-population variation, $17 \%$ among-population variation and 19\% amonggroup variation). However, there was more variation among groups and less variation at the among-population level in the L. perenne and $\times$ Festulolium comparison (Table 4).

Within-population variation of Irish $L$. perenne ecotypes accounted for $82 \%$ of the variation and amongpopulation variation accounted for $18 \%$. For the European L. perenne ecotypes, the situation was different. The within-population variation accounted for only $61 \%$ of the total variation, and the among-population variation accounted for 39\% (Table 4). For all AMOVA calculations, all results were highly significant $(P \leqslant 0.001)$. For analyses comparing the phylogeographic structure in the European/Near Eastern ecotypes, the percentages of variation accounted for by among- and within-population variation were similar for all the partitions tested (data not shown).

For all calculations comparing migration routes among-group and among-population variation was highly significant $(P \leqslant 0.001)$. All within-population variations were not significant. In both tests for evidence of a Mediterranean migration route, among-group variation was $\leqslant 0$ (Table 4 ). For the two tests investigating phylogeographic structure on a possible Danubian migration route (Southern vs Western Europe and Southern vs Eastern Europe), among-group variations were low but significant, 3 and $4 \%$, respectively (Table 4). Similarly, for both tests investigating phylogeographic structure on a possible North African migration route, among-group variations were low but significant, 2 and $4 \%$, respectively (Table 4). A post-glacial migration route appeared to be possible since among-group variation for this partition was $0(P \leqslant 0.001)$. For migration into Ireland from three neighbouring geographical groups, the lowest among-group variation was found in the partition between Southern European and Irish L. perenne ecotypes with only 5\%. This result was confirmed by a second Edward's Venn diagram (Supplementary Material C), where the highest number of haplotypes was shared among Irish L. perenne ecotypes and Southern European L. perenne ecotypes (14, Supplementary Material C). The values for Western European and Northern European groups were higher, each $10 \%$, respectively. 


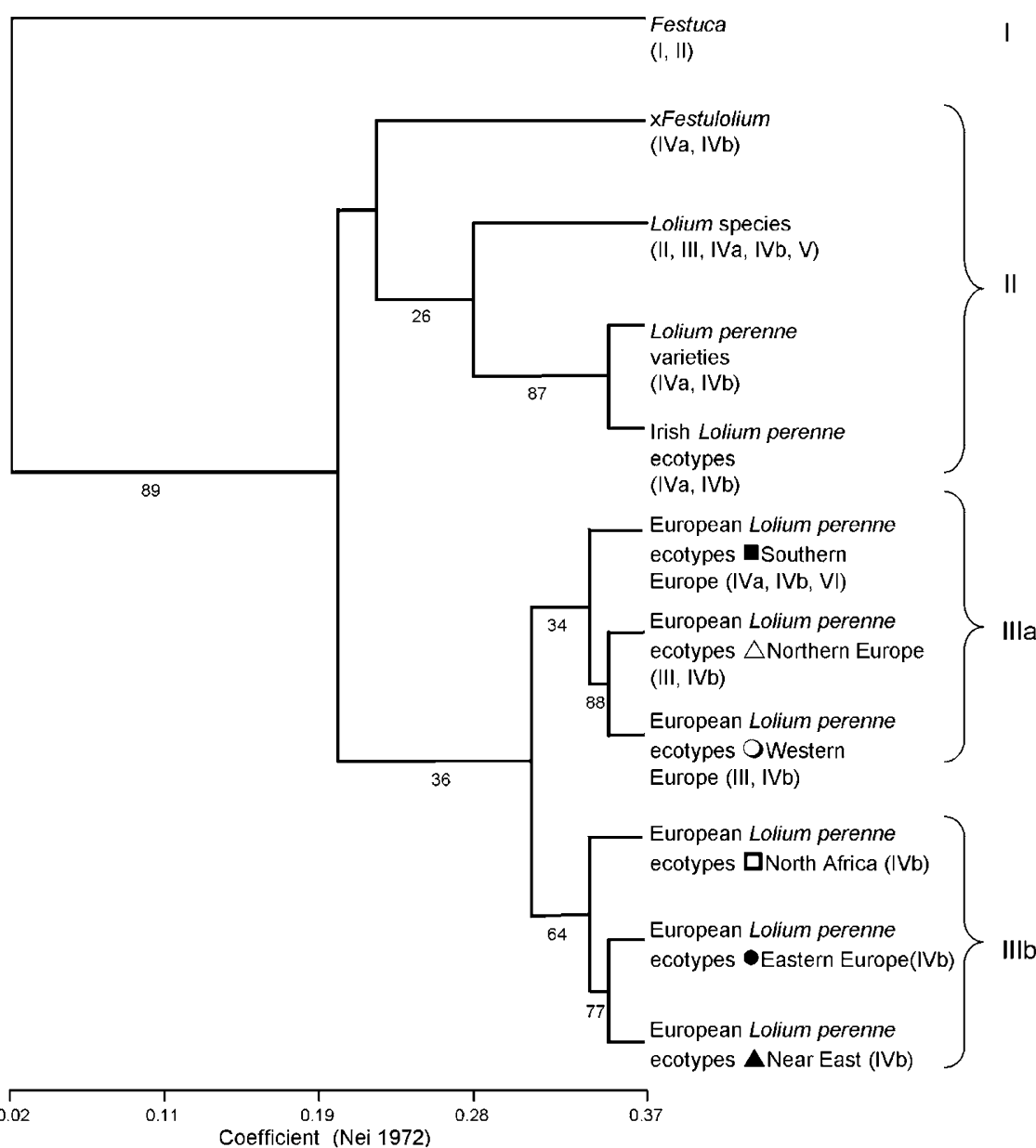

Figure 1 Unrooted dendrogram showing similarities between groups of accessions, constructed using the unweighted pair group method with arithmetic means (UPGMA) method (Sneath and Sokal, 1973) as implemented in NTSYSpc V2.2 (Rohlf, 2005), based on Nei's genetic distance measures (Nei, 1972). Numbers on the branches are percentage bootstrap values generated in NTSYSpc V2.2 (Rohlf, 2005). Symbols in parentheses are the groups where those species are present in Supplementary Material A.

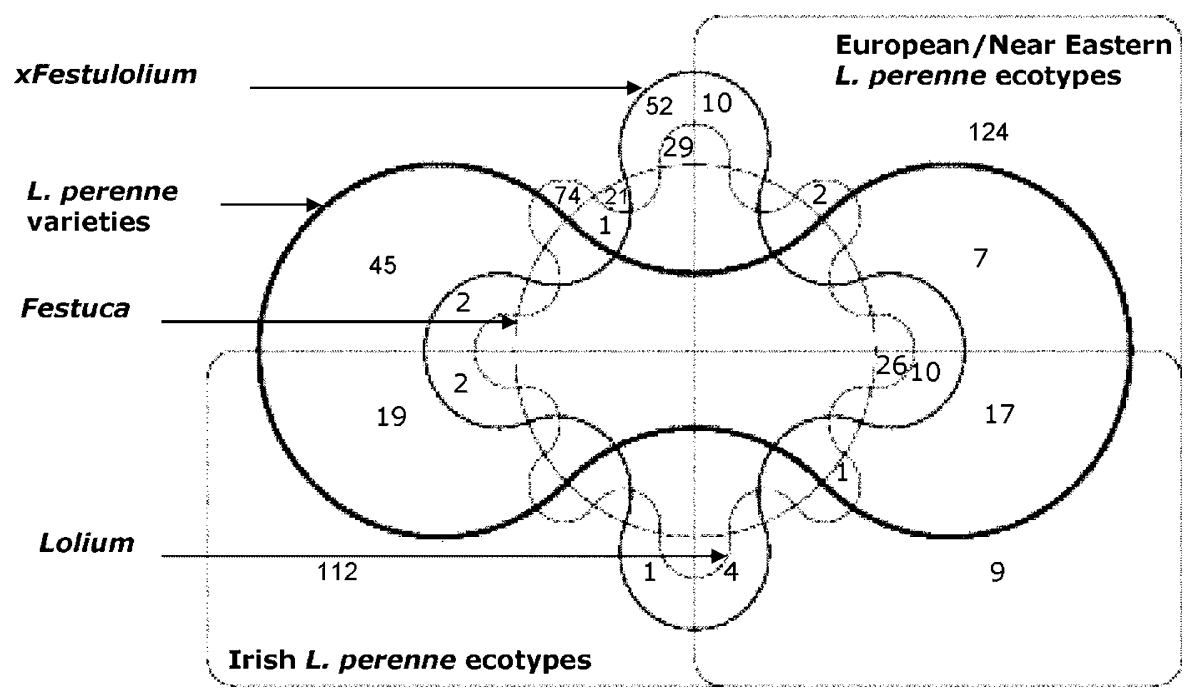

Figure 2 Edwards' Venn diagram demonstrating shared and unique haplotypes for the Irish L. perenne ecotypes, European/Near Eastern L. perenne ecotypes, L. perenne commercial varieties, other Lolium species, $\times$ Festulolium varieties and Festuca species. Shared haplotypes among groups are in intersects. 
Table 3 Diversity statistics based on Nei's (1987) analysis of gene diversity in subdivided populations for geographical groups of L. perenne ecotypes, L. perenne breeding varieties, Lolium species, $\times$ Festulolium varieties and Festuca species

\begin{tabular}{|c|c|c|c|c|c|}
\hline & $\mathrm{N}_{i}$ & $\mathrm{~N}_{p}$ & $\mathrm{H}_{t}$ & $\mathrm{H}_{s}$ & $\mathrm{G}_{s t}$ \\
\hline Irish L. perenne ecotypes & 480 & 30 & 0.312 & 0.238 & 0.238 \\
\hline European and other geographic regional L. perenne ecotypes (total) & 496 & 32 & 0.330 & 0.188 & 0.431 \\
\hline Northern Europe $\triangle$ & 100 & 7 & 0.327 & 0.197 & 0.397 \\
\hline North Africa $\square$ & 48 & 3 & 0.254 & 0.177 & 0.301 \\
\hline Near East $\boldsymbol{\Delta}$ & 60 & 4 & 0.233 & 0.146 & 0.373 \\
\hline Southern Europe $\mathbf{\square}$ & 128 & 8 & 0.359 & 0.217 & 0.395 \\
\hline Western Europe $\bigcirc$ & 80 & 5 & 0.347 & 0.191 & 0.449 \\
\hline Eastern Europe • & 80 & 5 & 0.247 & 0.166 & 0.328 \\
\hline L. perenne varieties & 259 & 16 & 0.302 & 0.216 & 0.285 \\
\hline$\times$ Festulolium & 140 & 9 & 0.318 & 0.227 & 0.285 \\
\hline Other Lolium species & 136 & 11 & 0.341 & 0.142 & 0.585 \\
\hline Festuca species & 64 & 6 & 0.269 & 0.077 & 0.716 \\
\hline
\end{tabular}

Abbreviations: $G_{\mathrm{st}}$, coefficient of genetic differentiation; $H_{\mathrm{s}}$, diversity within subdivided populations; $H_{\mathrm{t}}$, total gene diversity; $N_{\mathrm{i}}$, number of individuals; $N_{\mathrm{p}}$, number of populations.

\section{Discussion}

\section{Characterization of cpDNA diversity at allelic and haplotypic level}

All accessions displayed a high level of cpDNA SSR allelic variation and considerable numbers of haplotypes were found within ecotypes, within cultivars and within closely related groups of accessions. A total of 511 haplotypes were detected with an average of 10.4 haplotypes per accession. Partially this high variation within populations could be explained by the common and geographically widespread use of $L$. perenne as a cultivated agricultural species. Seed dispersal is the main factor affecting maternal plastid diversity over geographic space. Seeds could have been moved deliberately and accidentally by grazers, birds and wind or by human involvement including seed trade. We have detected numerous chloroplast haplotypes within Lolium populations, which would suggest that seed dispersal is high between populations over large geographical areas.

Some of the marker loci tested in our study were more variable than others. There are several possible reasons for this. For example, the locus with the least amount of variation, TeaCpSSR7, is located within a gene $(\operatorname{tr} n \mathrm{H})$, whereas the locus with the highest amount of variation, TeaCpSSR3, is located in an intergenic spacer region (trnL-F intergenic spacer). This would be in accordance with the theoretical expectations for the evolution rate of these particular genomic regions (Wolfe et al., 1987). Moreover, the length of the cPSSR PCR product could play a role. At locus TeaCpSSR7, the length of the PCR product is shorter than the product at locus TeaCpSSR3 (McGrath et al., 2006). The length of the PCR product could reduce the theoretical possible likelihood of variation for a given length of sequence. Furthermore, longer cPSSR loci are known to display higher levels of molecular divergence than shorter cPSSR loci (Provan et al., 2001) partially because slipped-strand mispairing during DNA replication is greater within these regions.

Individual accessions showed a range of variation in gene diversity values, particularly among the ecotypes. For example, gene diversity values in Irish $L$. perenne ecotypes ranged from 0.122 to 0.333 (Table 1). Different factors acting on the individual populations may have affected the cytoplasmic diversity of the ecotypes.
Isolation and fragmentation of individual populations could reduce diversity values, whereas increased movement of seed between certain ecotypes could have caused proportionally increased diversity.

The diversity of the Irish L. perenne ecotype populations was slightly less than in European L. perenne populations $\left(H_{\mathrm{t}}: 0.312\right.$ and 0.330 , respectively). This could be explained in relation to the geographic position of Ireland as an island that has isolated Irish L. perenne ecotypes from the populations on the continent. If continental Europe was the centre of origin for L. perenne, the Irish diversity levels may be expected to be lower. However, plastid diversity is not markedly lower in Irish than in European L. perenne ecotypes and this could possibly be due to the thorough collection strategy of the Irish team in establishing the ECPGR collection that aimed to maximize the ecogeographical spread of Irish $L$. perenne populations. The $G_{\text {st }}$ value of the Irish L. perenne ecotypes is almost half that of the European/ Near Eastern L. perenne ecotypes (0.238 and 0.431, respectively). This indicates that the European/Near Eastern L. perenne ecotypes are more markedly different from each other than the Irish L. perenne ecotypes are from each other. This was not unexpected as there was often a larger geographic distance between European than between Irish populations. Because of this it may be argued that Irish ecotype accessions could be considered as a big meta-population. However, significant AMOVA variance components among Irish populations would contradict such a meta-population theory.

Haplotypes were also shown to be highly heterogenous within populations, with only 11 out of 104 populations containing no unique haplotypes (Table 1). This level of heterogeneity in populations indicated that seed for these populations was derived from many maternal lines, which is in accordance with breeding principles for allogamous forage species (Acquaah, 2006). Fifteen haplotypes were found in a study of 447 L. perenne and L. rigidum individuals (3\%) by Balfourier et al. (2000), 41 haplotypes in a study of 168 Fraxinus excelsior individuals (24\%) by Harbourne et al. (2005) compared to 511 haplotypes in 1575 individuals (32\%) in this study. While $27 \%$ of haplotypes detected in the study by Balfourier et al. (2000) were unique to single populations, $71 \%$ of haplotypes detected in this study were unique to single populations. Our findings are in 
Table 4 Analysis of molecular variance (AMOVA) for Irish and European L. perenne accessions, $\times$ Festulolium varieties and subgroups within European/Near Eastern L. perenne ecotype accessions

\begin{tabular}{|c|c|c|c|c|c|c|}
\hline Source of variation & $\begin{array}{l}\text { Migration } \\
\text { route }\end{array}$ & d.f. & $S S D$ & $\begin{array}{l}\text { Variance } \\
\text { component }\end{array}$ & $\begin{array}{l}\text { Variance } \\
(\%)\end{array}$ & $\mathrm{P}^{\mathrm{a}}$ \\
\hline Irish ecotypes & NA & & & & & \\
\hline Among populations & & 29 & 140.17 & 0.23 & 18 & $* * *$ \\
\hline Within populations & & 449 & 493.29 & 1.10 & 82 & $* * *$ \\
\hline European ecotypes & NA & & & & & \\
\hline Among populations & & 31 & 312.84 & 0.59 & 39 & $* * *$ \\
\hline Within populations & & 462 & 427.57 & 0.93 & 61 & $* * *$ \\
\hline Irish ecotypes vs European ecotypes & NA & & & & & \\
\hline Among groups (Irish ecotypes vs European ecotypes) & & 1 & 95.24 & 0.18 & 11 & $* * *$ \\
\hline Among populations/within groups & & 61 & 453.01 & 0.42 & 26 & $* * *$ \\
\hline Within populations & & 911 & 920.86 & 1.01 & 63 & $* * *$ \\
\hline Irish L. perenne ecotypes vs $\times$ Festulolium varieties & NA & & & & & \\
\hline $\begin{array}{l}\text { Among groups (Irish L. perenne ecotypes vs } \\
\times \text { Festulolium varieties) }\end{array}$ & & 1 & 74.98 & 0.32 & 19 & $* * *$ \\
\hline Among populations/within groups & & 38 & 201.84 & 0.28 & 17 & $* * *$ \\
\hline Within populations & & 580 & 622.31 & 1.07 & 64 & $* * *$ \\
\hline European L. perenne ecotypes vs $\times$ Festulolium varieties & NA & & & & & \\
\hline $\begin{array}{l}\text { Among groups (European L. perenne ecotypes vs } \\
\times \text { Festulolium varieties) }\end{array}$ & & 1 & 47.00 & 0.17 & 10 & $* * *$ \\
\hline Among populations/within groups & & 40 & 374.51 & 0.56 & 34 & $* * *$ \\
\hline Within populations & & 593 & 556.59 & 0.94 & 56 & $* * *$ \\
\hline Near East $\boldsymbol{\Delta}$ ws Southern Europe $\boldsymbol{\square}$ & $\begin{array}{l}\text { Mediterranean, } \\
\text { Danubian }\end{array}$ & & & & & \\
\hline $\begin{array}{l}\text { Among groups (Near Eastern ecotypes vs } \\
\text { Southern European ecotypes) }\end{array}$ & & 1 & 8.95 & 0.00 & -1 & $* * *$ \\
\hline Southern Europe $\mathbf{q}$ western Europe $\bigcirc$ & Mediterranean & & & & & \\
\hline $\begin{array}{l}\text { Among groups (Southern European ecotypes vs } \\
\text { Western European ecotypes) }\end{array}$ & & 1 & 11.76 & 0.00 & 0 & $* * *$ \\
\hline Southern Europe vs Eastern Europe • & Danubian & & & & & \\
\hline $\begin{array}{l}\text { Among groups (Southern European ecotypes vs } \\
\text { Eastern European ecotypes) }\end{array}$ & & 1 & 18.48 & 0.06 & 4 & $* * *$ \\
\hline Eastern Europe • vs Northern Europe $\Delta$ & Danubian & & & & & \\
\hline $\begin{array}{l}\text { Among groups (Eastern European ecotypes vs } \\
\text { Northern European ecotypes) }\end{array}$ & & 1 & 12.92 & 0.04 & 3 & $* * *$ \\
\hline Near East $\boldsymbol{\Delta}$ vs North Africa $\square$ & North African & & & & & \\
\hline $\begin{array}{l}\text { Among groups (Near Eastern ecotypes vs } \\
\text { North African ecotypes) }\end{array}$ & & 1 & 10.01 & 0.03 & 2 & *** \\
\hline North Africa $\square$ vs Southern Europe $\square$ & North African & & & & & \\
\hline $\begin{array}{l}\text { Among groups (North African ecotypes vs } \\
\text { Southern European ecotypes) }\end{array}$ & & 1 & 15.65 & 0.08 & 4 & $* * *$ \\
\hline All north of the alps ecotypes vs all south of the alps ecotypes & Post-glacial & & & & & \\
\hline Among groups (All northern ecotypes vs all southern ecotypes) & & 1 & 10.63 & 0.00 & 0 & $* * *$ \\
\hline Among populations/within groups & & 31 & 312.45 & 0.59 & 39 & $* * *$ \\
\hline Within populations & & 477 & 444.82 & 0.93 & 61 & NS \\
\hline Southern Europe $\mathbf{\square}$ Irish ecotypes & Into Ireland & & & & & \\
\hline Among groups (Southern European ecotypes vs Irish ecotypes) & & 1 & 21.91 & 0.08 & 5 & $* * *$ \\
\hline Among populations/within groups & & 36 & 216.10 & 0.31 & 21 & $* * *$ \\
\hline Within populations & & 568 & 630.13 & 1.09 & 74 & $* *$ \\
\hline Western Europe $\bigcirc$ vs Irish ecotypes & Into Ireland & & & & & \\
\hline Among groups (Western European ecotypes vs Irish ecotypes) & & 1 & 26.49 & 0.15 & 10 & $* * *$ \\
\hline Among populations/within groups & & 33 & 192.76 & 0.30 & 19 & $* * *$ \\
\hline Within populations & & 524 & 564.79 & 1.08 & 71 & $* * *$ \\
\hline Northern Europe $\Delta$ vs Irish ecotypes & Into Ireland & & & & & \\
\hline Among groups (Northern European ecotypes vs Irish ecotypes) & & 1 & 31.30 & 0.16 & 10 & $* * *$ \\
\hline Among populations/within groups & & 35 & 198.72 & 0.29 & 19 & $* * *$ \\
\hline Within populations & & 542 & 583.69 & 1.08 & 71 & $* * *$ \\
\hline
\end{tabular}

Abbreviations: d.f., degrees of freedom; NA, not applicable; NS, not significant; SSD, sum of squared differences.

$a_{* * *} P<0.01$ and $* * * P<0.001$. 
accordance with findings of Fjellheim et al. (2006) in Festuca study including $L$. perenne for comparative reasons. Their analysis demonstrated that $L$. perenne accessions had four times as many haplotypes as F. pratensis. These authors suggested that a lower variation in F. pratensis could be due to the greater age of the species $F$. pratensis and because the chloroplast variation in $F$. pratensis was largely decimated in the Eemian interglacial period, where most of Europe was densely forested, while $F$. pratensis is a shade intolerant species.

\section{Plastid genome identification, cytoplasmic gene pool characterization, and the study of hybridization and introgression}

While none of the alleles for each of the ten cpSSRs were diagnostic for individual populations, several of the alleles found were unique to specific population groups (Table 2). It is possible that germplasm from these collections could be identified by genotyping these cpSSR markers if sufficient numbers of individuals are tested. Particularly useful for this purpose could be marker TeaCpSSR8, where half of the alleles were unique to Irish or European L. perenne ecotype accessions, respectively (Table 2). At the haplotype level, the majority of haplotypes detected were unique to specific groups of populations (Figure 2). While the high level of heterogeneity of haplotypes within populations made it difficult to assign individuals to specific populations, it was possible to use these haplotypes to assign individuals to specific groups. For example, 22\% of haplotypes were specific to the Irish L. perenne ecotypes, and $24 \%$ of haplotypes were specific to the other European L. perenne ecotypes. These haplotypes have potential to distinguish geographic L. perenne ecotypes and accessions (Supplementary Material B).

The high level of variation, both allelic and haplotypic, in the European and Irish L. perenne ecotype collection in comparison with L. perenne cultivars suggests that the full cytoplasmic diversity is still underexploited in breeding material (Table 2 and Figure 2). Ecotypes with unique plastid variation not present in breeding material could be useful to expand the cytoplasmic gene pool for breeding of the species. A wide variation in plastid type can be useful to enhance the possibility of yield gains and yield stability as demonstrated on a data set for potato (Provan et al., 1999). For both UPGMA dendrograms (Supplementary Material A and Figure 1), the ten cpSSR markers were able to distinguish among Irish and European L. perenne ecotypes. This outcome indicated the usefulness of these ten cPSSR markers to identify cytoplasmic gene pools in ecotypes and breeding L. perenne germplasm.

Identification of plastid type is also useful for the study of introgression and hybridization (Hodkinson et al., 2002; Johannessen et al., 2005), as plastid marker information can identify the source of introgression and can be used in parentage analysis. For example, L. temulentum (L11) grouped with two Festuca species, NL1 and NL4 (Supplementary Material A, group II). This could be an indication of introgression of the plastid genome from Festuca species into Lolium. AMOVA analysis of Irish and European and Near Eastern L. perenne ecotypes vs the $\times$ Festulolium cultivars showed there was almost twice as much of the among-group variation between Irish $L$. perenne ecotypes and $\times$ Festulolium cultivars than between the European/Near Eastern L. perenne ecotypes and $\times$ Festulolium cultivars (Table 4). This could suggest more movement of cytoplasmic material between European ecotypes and $\times$ Festulolium cultivars than with Irish $L$. perenne ecotypes. Six out of nine $\times$ Festulolium cultivars grouped with the European L. perenne ecotypes (Supplementary Material A), which also could indicate introgression from European and Near Eastern L. perenne ecotypes into $\times$ Festulolium.

Plastid identification could also be used to verify that seed or seedlings derived from crosses in breeding programmes were assigned to the correct maternal parent (Gauthier et al., 1997). This could be particularly helpful for Lolium breeding in which multiple maternal lines are used in plant breeding (top cross breeding).

\section{Phylogenetic and phylogeographic genetic structure of Lolium}

Studying plastid DNA variation can contribute to phylogenetic analysis. UPGMA data demonstrated that two broad-leaved Festuca species, F. arundinacea and F. pratensis, and three narrow-leaved Festuca species, F. pratensis, Festuca rubra and Festuca vivipara, grouped together, respectively (Supplementary Material A). The broad-leaved Festuca species grouped closer to Lolium. Both of these findings were in agreement with previous studies (Darbyshire and Warwick, 1992; Catalan et al., 1997, 2004; Charmet et al., 1997; Torrecilla et al., 2004). However, some unusual groupings have occurred in the UPGMA dendrogram (Supplementary Material A). For example, one of the European L. perenne ecotypes ( $\left.\boldsymbol{\square}_{17}\right)$ was positioned outside all other Lolium accessions. This particular accession was from Sardinia where previously a high degree of diversity has been found for other species (Papa et al., 1998). Moreover, unlike other studies (Catalan et al., 1997, 2004; Charmet et al., 1997; Torrecilla et al., 2004), no separation of allogamous and autogamous Lolium species was found. These unusual groupings could be explained by high homoplasy in the data set caused by rapid molecular evolution at the loci studied. Parallel evolution at these loci would therefore be expected to be high and this would obscure phylogenetic signal of the markers (Flannery et al., 2006). They are thus potentially more useful for assessing variation within species than among species.

A loose correlation of genetic and geographic distances was detected with a Mantel test for the ecotypes were an exact geographic position was available $(r=0.33)$. While studies have tested the correlation between nuclear and geographic distances such as Cresswell et al. (2001), this is the first study to test the correlation between plastid genetic and geographic distances in L. perenne. We believe the lack of correlation is due to both the high within population plastid diversity and the high degree of seed-mediated gene flow, natural and human related.

The AMOVA analyses indicated that most of the variation in populations used in this study was withingroups and individual populations, but that there was also significant population genetic structuring among groups (Table 4). Generally, higher among-population variance component values are comparable to AMOVA 
analysis results of other studies of L. perenne populations using nuclear markers (Bolaric et al., 2005).

The results for the AMOVA analysis showing the proportion of variance within or among groups were also useful for assessing broad-scale biogeographical patterns. For comparisons among groups examining the Mediterranean migration route in relation to other possible migration routes, the variance components between partitions for the Danubian and North African routes were 0 or close to 0 . When a variance component is close to 0 , it can mean that there is no population genetic structure (Schneider et al., 2000). Close to 0 or 0 values can also be an indication that samples among groups are more closely related to each other than samples within groups. This would indicate that these population groups are closer to each other than to groups showing a higher among-group variance component. For this data set it could be an indication of a Mediterranean movement of $L$. perenne from the Near East across Southern Europe into North Western Europe, Ireland. This is in accordance with one movement theory of L. perenne across Europe as proposed by Balfourier et al. (2000). This finding was substantiated in our study by the result of an AMOVA for post-glacial partitioning of south of the Alps ecotypes against north of the Alps ecotypes. In this case, among-group variation was 0 as well (Table 4). The post-glacial movement hypothesis can be further supported by our UPGMA data (Figure 1). Southern European, Northern European and Western European L. perenne ecotypes were grouped together and were distinct from the other European/Near Eastern $L$. perenne ecotypes. This indicated that these population groups were closer to each other than to other geographic groups and that movement of seed between these groups has occurred. Finally, the hypothesis that L. perenne most likely moved from the southern Europe into Ireland can be supported by the lowest amonggroup variation value in the AMOVA analysis (Table 2: 5\%) for Southern Europe/Irish ecotype partition.

\section{Conclusion}

Allelic and haplotypic variation was extremely high within and between Irish and European L. perenne ecotypes. Migration of seed material by natural or anthropogenic means, including plant breeding, could contribute to this high level of variability. High plastid diversity was clearly persisting in populations. The cPSSR markers were shown to be extremely useful for characterizing variation in our accessions and have enabled the identification of cytoplasmic genepools and maternal lineages. The plastid type of individual populations could not be unambiguously identified, but groups of populations could be successfully identified. This suggests that an increase in the number of cPSSR markers would increase the likelihood of identifying individuals within population groups. Our findings describe broad-scale biogeographical patterns of population genetic structure in this highly heterogenous species. Furthermore, some evidence was provided to support possible broad-scale prehistorical geographical migrations. A pathway of migration from Southern Europe to Northwest Europe including Ireland is most likely.

\section{Acknowledgements}

SMcG is supported by a Teagasc PhD Walsh Fellowship. The Irish Department of Agriculture and Food supported the research with additional grant aid under the 'Genetic Resources for Food and Agriculture' scheme. We are grateful for discussions with Dr Vincent Connolly. Seeds were kindly provided by the genebank of the Institute of Plant Genetics and Crop Plant Research (IPK) Gatersleben/Germany, the National Genetic Resources Program (GRIN)/USA, Dr Radomir Capka of the Plant Breeding Station Hladke Zivotice/Czech Republic, Dr Alan Stewart of PGG Wrightson/New Zealand and Dr Ian Thomas of the genebank at International Grassland and Environmental Research (IGER)/Wales. We are also grateful for the excellent technical genotyping assistance of Ms Teresa Marie Charles.

\section{References}

Acquaah G (ed) (2006). Breeding cross-pollinated species. Principles of Plant Genetics and Breeding. Blackwell Publishing: Oxford. pp 313-333.

Balfourier F, Imbert C, Charmet G (2000). Evidence for the phylogeographic structure in Lolium species related to the spread of agriculture in Europe A cpDNA study. Theor Appl Genet 101: 131-138.

Bolaric S, Barth S, Melchinger AE, Posselt UK (2005). Genetic diversity in European perennial ryegrass cultivars investigated with RAPD markers. Plant Breed 124: 161-166.

Catalan P, Kellogg EA, Olmstead RG (1997). Phylogeny of Poaceae subfamily Pooideae based on chloroplast $n d h \mathrm{~F}$ gene sequences. Mol Phylogenet Evol 8: 150-166.

Catalan P, Torrecilla P, Lopez Rodriguez JA, Olmstead RG (2004). Phylogeny of the Festucoid grasses of subtribe Loliinae and allies (Pooeae, Pooideae) inferred from ITS and trnL-F sequences. Mol Phylogenet Evol 31: 517-541.

Charmet G, Balfourier F, Chatard V (1996). Taxonomic relationships and interspecific hybridization in the genus Lolium (grasses). Genet Resour Crop Evol 43: 319-327.

Charmet G, Ravel C, Balfourier F (1997). Phylogenetic analysis in the Festuca-Lolium complex using molecular markers and ITS rDNA. Theor Appl Genet 94: 1038-1046.

Connolly V (2000). Collection and conservation of forage species from old pasture ecosystems. Irish J Agric Food Res 39: $476-477$.

Cresswell A, Sackville Hamilton NR, Roy AK, Viegas MF (2001). Use of amplified fragment length polymorphism markers to assess genetic diversity of Lolium species from Portugal. Mol Ecol 10: 229-241.

Daniell H, Kumar S, Dufourmantel N (2005). Breakthrough in chloroplast genetic engineering of agronomically important crops. Trends Biotechnol 23: 238-245.

Darbyshire SJ, Warwick SI (1992). Phylogeny of North American Festuca (Poaceae) and related genera using chloroplast DNA restriction site variation. Can J Bot 70: 2415-2429.

Excoffier L, Smouse PE, Quattro JM (1992). Analysis of molecular variance inferred from metric distances among DNA haplotypes: application to human mitochondrial DNA restriction data. Genetics 131: 479-491.

Fjellheim S, Rognli OA, Fosnes K, Brochmann C (2006). Phylogeographical history of the widespread meadow fescue (Festuca pratensis Huds.) inferred from chloroplast DNA sequences. J Biogeograph 33: 1470-1478.

Flannery ML, Mitchell FJG, Coyne S, Kavanagh TA, Burke JI, Salamin $N$ et al (2006). Plastid genome characterisation in Brassica and Brassicaceae using a new set of nine SSRs. Theor Appl Genet 113: 1221-1231. 
Gauthier P, Lumaret R, Bedcarrats A (1997). Chloroplast-DNA variation in the genus Lotus (Fabaceae) and further evidence regarding the maternal parentage of Lotus corniculatus L. Theor Appl Genet 95: 629-636.

Goldstein DB, Linares AR, Cavalli-Sforza LL, Feldman MW (1995). An evaluation of genetic distances for use with microsatellite loci. Genetics 139: 463-471.

Gray JC (2005). Regulation of nuclear gene expression by plastid signals. In: Moller SG (ed). Plastids. Blackwell Publishing: Oxford. pp 237-267.

Hallden C, Gertsson B, Sall T, Lind-Hallden C (1993). Characterisation of organellar DNA in alloplasmic lines of Brassica napus L. Plant Breed 111: 185-191.

Harbourne ME, Douglas GC, Waldren S, Hodkinson TR (2005). Characterization and primer development for amplification of chloroplast microsatellite regions of Fraxinus excelsior. J Plant Res 118: 339-341.

Hodkinson TR, Chase MW, Lledo MD, Salamin N, Renvoize SA (2002). Phylogenetics of Miscanthus, Saccharum and related genera (Saccharinae, Andropogonae, Poaceae) based on DNA sequences from ITS nuclear ribosomal DNA and plastid $\operatorname{trn} \mathrm{L}$ intron and $\operatorname{trn} \mathrm{L}-\mathrm{F}$ intergenic spacers. J Plant Res 115: 381-392.

Huang SX, Sirikhachornkit A, Faris JD, Su X, Gill BS, Haselkorn $R$ et al (2002). Phylogenetic analysis of the acetyl-CoA carboxylase and 3-phosphoglycerate kinase loci in wheat and other grasses. Plant Mol Biol 48: 805-820.

Humphreys MW, Yadav RS, Cairns AJ, Turner LB, Humphreys J, Skøt L (2006). A changing climate for grassland research. New Phytologist 169: 9-26.

Johannessen MM, Andersen BA, Damgaard C, Jorgensen RB (2005). Maternal inheritance of chloroplasts between Brassica rapa and F1-hybrids demonstrated by cpDNA markers specific to oilseed rape and B. rapa. Mol Breed 16: 271-278.

Joshi SP, Ranjekar PK, Gupta VS (1999). Molecular markers in plant genome analysis. Curr Sci 77: 230-240.

McGrath S, Hodkinson TR, Salamin N, Barth S (2006). Development and testing of novel chloroplast microsatellite markers for Lolium perenne and other grasses (Poaceae) from de novo sequencing and in silico sequences. Mol Ecol Notes 6: 449-452.

Michalakis Y, Excoffier L (1996). A generic estimation of population subdivision using distances between alleles with special reference for microsatellite loci. Genetics 142: 1061-1064.

Nei M (1972). Genetic distance between populations. Am Nat 106: 283-292.

Nei M (1973). Analysis of gene diversity in subdivided populations. Proc Natl Acad Sci USA 70: 3321-3323.
Nei M (1987). Molecular Evolutionary Genetics. Columbia University Press: New York.

Papa R, Attene G, Barcaccia G, Ohgata A, Konishi T (1998). Genetic diversity in landrace populations of Hordeum vulgare L. from Sardinia, Italy, as revealed by RAPDs, isozymes and morphophenological traits. Plant Breeding 117: 523-530.

Powell W, Morgante M, McDevitt R, Vendramin GG, Rafalski JA (1995). Polymorphic simple sequence repeat regions in chloroplast genomes: applications to the population genetics of pines. Proc Natl Acad Sci USA 92: 7759-7763.

Provan J, Powell W, Dewar H, Bryan G, Machray GC, Waugh R (1999). An extreme cytoplasmic bottleneck in the modern European cultivated potato (Solanum tuberosum) is not reflected in decreased levels of nuclear diversity. Proc $R$ Soc Lond B Biol Sci 266: 633-639.

Provan J, Powell W, Hollingsworth PM (2001). Chloroplast microsatellites: new tools for studies in plant ecology and evolution. Trends Ecol Evol 16: 142-147.

Rohlf F (2005). NTSYSpc: Numerical Taxonomy System, Version 2.2 (2). Exeter Publishing Ltd: Setauket, NY.

Saski C, Lee SB, Daniell H, Wood TC, Tomkins J, Kim HG et al. (2005). Complete chloroplast genome sequence of Glycine max and comparative analyses with other legume genomes. Plant Mol Biol 59: 309-322.

Schneider S, Roessli D, Excoffier L (2000). Arlequin: A Software for Population Genetics Data Analysis. Version 2.000. Genetics and Biometry Lab, Department of Anthropology, University of Geneva.

Sneath P, Sokal R (1973). Numerical Taxonomy. W.H. Freeman and Company: San Francisco.

Torrecilla P, Lopez Rodriguez JA, Catalan P (2004). Phylogenetic relationships of Vulpia and related genera (Poeae, Poaceae) based on analysis of ITS and trnL-F sequences. Ann Miss Bot Gard 91: 124-158.

United Nations Publication (1999). Standard Country or Area Codes for Statistical Use (Department of Economic and Social Affairs, United Nations) Revision 4. url: http://millenniumindicators.un.org/unsd/methods/m49/m49.htm.

Weir BS, Cockerham CC (1984). Estimating F-statistics for the analysis of population-structure. Evolution 38: 1358-1370.

Wolfe KH, Li W-H, Sharp PM (1987). Rates of nucleotide substitution vary greatly among plant mitochondrial, chloroplast, and nuclear DNAs. Proc Natl Acad Sci USA 84: 9054-9058.

Yeh FC, Boyle T (1997). Population genetic analysis of codominant and dominant markers and quantitative traits. Bel J Bot 129: 157.

Supplementary Information accompanies the paper on Heredity website (http://www.nature.com/hdy) 